\title{
AN EXPERIMENTAL STUDY OF ANNULAR DIFFUSER \\ PERFORMANCE
}

Mofreh H. Hamed and Elsayed H. Farag. Department of Mechanical Power Engineering, Faculty of Engineering, Menoufiya University, Shebin El-Kom, Egypt

\begin{abstract}
:
The work described in this paper is concerned mainly with an experimental investigation of subsonic turbulent flows through annular diffusers having divergence angles of 17.5 and 9 degrees for the casing and hub, respectively, with an area ratio of 2.1. The performance of the tested diffuser was measured for a variety of throat dimensionless velocity $(\lambda)$ using different strut geometries. Two kinds of struts with airfoil and cylindrical cross-sections were installed separately at different locations inside the tested diffuser. The results indicated that, the magnitude of the dimensionless velocity $(\lambda)$ at the throat perimeter is dependent upon the strut cross-section and its location. The performance of the tested diffuser is improved when cylindrical struts with suitable diameters are set at an appropriate position in the diffuser. Increasing the blockage due to the presence of struts was found to be substantially increases the tendency of separation. The total loss coefficient due to nonuniformity of flow at the diffuser entrance was found to be significantly greater on the casing than that on the hub. It appeared also that, a better performance was achieved with the cylindrical struts due to the increase in turbulent mixing in the wake region.
\end{abstract}

\section{1-INTRODUCTION:}

Annular diffusers appear quite commonly in turbo-machinery as exducers in turbines, diffusing elements in compressors and inter-stage duct system in multi-stage turbines. Such diffusers occur quite naturally in turbomachines because of the necessity of a fluid stream to flow over and around a central shaft and bearings.

Manuscript received from Dr. Mofreh H. Hamed

Accepted on : $25 / 3 / 2002$

Engineering Research Journal Vol 25, No 2, 2002 Minufiya University, Faculty of Engineering, Shebien El-Kom, Egypt, ISSN 1110-1180 
In view or the wide applications, diffuser flow is of paramount importance. A great deal of experimental and computational research has been devoted to turbulent flows in two-dimensional and conical diffusers. Annular diffusers have received less systematic investigation than other diffuser geometries. This is probably due to the large number of non-dimensional parameters involved in the description of the geometry. One of the earliest experiments on annular diffusers was that of Ainely [1]. He tested five diffusers with equal inner and outer cone angles and studied their pressure recovery under uniform inlet conditions. Johnston [2] extended these studies to include the effect of non-uniformity of the inlet velocity profile in the same five diffusers by adjusting the profile with variable blockage screens without the mention of flow patterns or regimes. The most notable contribution is that due to Sovran and Klomp [3]. They tested hundred geometries, nearly all of which had conically diverging center bodies with an inlet radius ratio of 0.55 and 0.70 . They showed that, parameters such as inlet radius ratio and wall angles did not affect the pressure recovery appreciably, while the diffuser area ratio and non-dimensional length are the controlling factors in determining optimum diffuser geometry. These testes were carried out with a thin inlet boundary layer and free discharge. Tyler and Williamson [4] extended the data used by Sovran and Klomp [3] for studying the effect of inlet boundary layer blockage on pressure recovery of optimum diffusers. They tested two annular diffusers. The main conclusion derived from their work was a confirmation of Sovran and Klomp's correlation for diffuser flows with inlet blockage below 0.05 . Their results indicated a significant dependence of diffuser pressure recovery on the thickness of turbulent inlet boundary layer. Stevens and Fry [5], Adenubi [6] and Stevens and Williams [7] carried out experimental work to investigate the flow regime and the performance of annular diffusers. Their results showed that a significant gain in the pressure recovery and a small increase in the total pressure loss due to increase inlet turbulence. The influence of wake behind struts on the performance of annular diffusers was examined by Senoo et al. [8]. They indicated that the struts induced a weak swirl, which improved the performance of the tested diffusers. Hoadley [9] investigated the growth of boundary layer in one annular diffuser of constant diameter center-body and found that separation on the outer wall was encountered. For more detailed discussions of flow phenomena and performance of annular diffusers refer to the recent extensive review of annular diffuser results by Klein [10]. The distortion of the flow produced by the struts, the inlet guide vanes and the separation from the walls in a gas turbine diffuser model were conducted by Ubertini and Desideri [11] and [12]. They also studied experimentally the performance analysis of an annular diffuser with and without struts to outline their detrimental effect. In these papers, the detrimental effect of struts was quantified in terms of overall performance and pressure losses. They concluded that the struts significantly increase the overall diffuser loss and this loss rise mainly occurs in the axial 
region of the struts and in the end wall regions, where flow separates from the hub and the casing.

It is clear from the literature survey that, the investigation and prediction of diffuser performance is very important to point out the optimum: design of the diffuser to provide experimental data on gas turbine exhaust diffusers that can be used to develop computational and design tools. Therefore, experimental tests were conducted to clarify the influences of the geometrical parameters and the type of strut that supporting the inner wall (hub) with the outer wall (casing) of annular diffuser on the performance of such diffusers. For this purpose, in this paper an annular diffuser is designed and fabricated. The measurements were concentrated on the total loss coefficient $\left(\zeta_{t}\right)$ created due to the flow separation, in addition to the losses generated by struts.

\section{2-THE EXPERIMENTAL FACULTYY}

The general arrangement of the experimental facility comprising twoscrew compressors (1), air reservoir and drying unit (2), a control valve (3), a subsonic wind tunnel (6), a settling tank (7), a test annular diffuser (10) are shown in Fig. (1). The annular diffuser is designed and fabricated from cast aluminum and machined smooth. The tested diffuser has an area ratio of 2.1. Air is drawn from the surrounding through the air intake fitted with air filters, into two screw compressors. The maximum delivering pressure from the automatically controlled compressors was 15 bar. Each of the two compressors is capable of delivering $3.24 \mathrm{~m}^{3} / \mathrm{min}$. The air from the air tanks flows through a 76-mm diameter pipeline and the flow rate is controlled and kept constant by means of a control valve (5). The settling pipe (4) is flanged to another settling pipe. To ensure the concentricity of the hub with the casing, the hub was accurately held in position by means of strut (9). Two kinds of struts with different cross-sections were installed separately. The geometry of tested annular diffuser and struts are shown in Figs. (2) and (3). The struts have cylindrical and airfoil cross-sections. The airfoil strut has $45-\mathrm{mm}$ chord and a maximum thickness of $2.7 \mathrm{~mm}$. Cylindrical struts of diameters of 3, 5.6, 8 and $13.5 \mathrm{~mm}$ were tested and their setting position was varied between (10 to $49 \mathrm{~mm}$ ). The air flowing through the test-rig was finally exhausted to the atmosphere. The characteristics of tested diffuser models with different struts are shown in Table (1). The test annular diffuser was provided with wall static pressure tapping around the diffuser casing and hub. The taps had $1.0 \mathrm{~mm}$ in diameter, were carefully drilled normal to the wall and stainless steel tubes of $1.0 \mathrm{~mm}$ outer diameter were pressed into the holes and flushed with the inside surface. The static pressure distributions around the casing and the hub were recorded using multi-tube water manometer. Furthermore, the total pressure at the diffuser inlet was measured using a calibrated pitot-tube.

The experimental uncertainty in the diffuser performance is estimated in accordance with Kline and McClintock [13]. The estimated uncertainties in static pressure and total loss coefficient are within, \pm 0.1 percent and \pm 1.5 percent, respectively. 
The following performance parameters are generally used to quantify the performance of a diffuser. The deceleration process $(\mathrm{h}-\mathrm{S}$ diagram) of flow through a diffuser can be represented as shown in Fig. (4). From this figure, the total loss coefficient $\left(\zeta_{t}\right)$ is derived and may be written in the following form,

$$
\zeta_{t}=\frac{\Delta h_{e}+\Delta h_{f}}{H_{1}}
$$

Where, $\Delta \mathrm{h}_{\mathrm{e}}, \Delta \mathrm{h}_{\mathrm{f}}$ and $\mathrm{H}_{1}$ are the losses due to the kinetic energy at the diffuser exit, the internal losses through the diffuser and the inlet total energy respectively. The total loss coefficient through the diffuser $\left(\zeta_{t}\right)$ can be expressed in terms of pressure differences, thus equation (1) can be written as,

$$
\zeta_{t}=\frac{1-\left(\frac{p_{2}}{p_{o}}\right)^{(\gamma-1) / \gamma}}{1-\left(\frac{p_{1}}{p_{o}}\right)^{(\gamma-1) / \gamma}}
$$

Where, $\mathrm{p}_{1}, \mathrm{p}_{2}$ and $\mathrm{p}_{\mathrm{o}}$ are the mean inlet static pressure measured at the diffuser throat around the hub and casing walls, outlet static pressure and total pressure, respectively. The mean inlet static pressure is calculated as the summation of the static pressure readings divided by the number of readings. The measurements were taken for different values of throat dimensionless velocity $(\lambda)$ which is defined by,

$$
\lambda^{2}=\mathrm{c}_{\mathrm{th}}^{2} / \mathrm{V}^{* 2}
$$

Where, $c_{t h}$ is the flow velocity at the throat section and is defined from the flow energy equation as follows,

$$
c_{t h}^{2}=\frac{2 \gamma R T_{o}}{(\gamma-1)}\left(1-\frac{T_{t h}}{T_{o}}\right)
$$

And $\mathrm{V}^{*}$ is the critical flow velocity, which expressed, Ref. [14]; as:

$$
\mathrm{V}^{*^{2}}=\frac{2 \gamma \mathrm{RT}_{0}}{\gamma+1}
$$

Using equations (4) and (5), the dimensionless velocity $(\lambda)$ at the throat can be formulated as follows,

$$
\lambda=\left[\frac{\gamma+1}{\gamma-1}\left[1-\left(\frac{\mathrm{p}_{1}}{\mathrm{p}_{\mathrm{o}}}\right)^{(\gamma-1) / \gamma}\right]\right]^{1 / 2}
$$

It is important to study the effect of struts on the total loss coefficient compared with that in the case of no-struts. It is evident that the effective flow area is decreased due to the presence of struts and it affects the total loss coefficient. Therefore, the dimensionless difference in the total loss coefficient $(\Delta \zeta)$ in the absence and presence of struts can be calculated as,

$$
\Delta \zeta=\left(\zeta_{o}-\zeta_{t}\right) / \zeta_{o}
$$


where $\zeta_{0}$ is the total loss coefficient in the case of no-struts. The change in flow area due to the presence of struts is taken as,

$$
\Delta F=\left(F_{o}-F_{t}\right) / F_{o}
$$

where, $F_{o}$ is the flow area in the case of no-struts and $F_{t}$ is the flow area at maximum strut thickness.

The measurements are conducted at a Reynolds number ranged from $2 \times 10^{5}$ to $5 \times 10^{5}$ based on the hydraulic diameter at the throat and the corresponding dimensionless inlet velocity at the throat $(\lambda)$ ranged from 0.2 to 0.45 .

\section{4-RESULTS AND DISCUSSION}

In this section, the overall performance of the diffuser with struts and also without struts are discussed.

\section{4-1 Diffuser with cylindrical struts}

\section{4-1-1 Effect of strut diameter}

Experimental results shown in Fig. (5) shows that, cylindrical struts with smaller diameter $(\mathrm{d}=3 \mathrm{~mm})$ did not affect the total loss coefficient $\left(\zeta_{\mathrm{t}}\right)$ of the diffuser, cases 4,5 and 6 , Table-1. This may be attributed to that increasing the internal energy compensated the losses due to outlet kinetic energy and consequently the total loss coefficient doesn't change. While in cases 4 and 5 when install struts with diameter $(d=8 \mathrm{~mm}, S=36 \mathrm{~mm})$ the total loss coefficient increases compared with that in cases of without struts and smaller strut diameter. It is also seen from this figure that the total loss coefficient increases as the strut diameter increases, $(d=13.5 \mathrm{~mm}, \mathrm{~S}=10 \mathrm{~mm})$, on account of an additional loss caused by the wake behind struts

\section{4-1-2 Effect of strut location}

Figure (5) shows also that the total loss coefficient may be significantly affected by the strut location in the diffuser, cases 4 and 5 ( $d=8$ $\mathrm{mm}$ ). This is because, when the strut is set near the throat $(\mathrm{S}=36 \mathrm{~mm})$, case 5 , the inlet passage becomes too narrow and the total loss coefficient is increased, as shown in case 5 compared with the clear diffuser. On the other side, equations (7) and (8) can be used to quantify the diffuser performance as shown in Fig. (6). It is shown from this figure that, for throat dimensionless velocity $\lambda=0.37$, a maximum wasted total loss occurs for $\Delta \mathrm{F}=9$ to $10 \%$ and has a higher value when the strut is located near the throat, $S=36 \mathrm{~mm}$. Then, the optimum arrangement (diameter and position) which gives a minimum total loss coefficient $\left(\zeta_{\mathrm{t}}\right)$ with a suitable strut diameter and, in turn, the maximum diffuser performance can be determined

\section{4-2 Diffuser with airfoil struts}

Figure (7) shows the effect of location and number of airfoil struts on the total loss coefficient. The figure indicates for clean diffuser that, the total loss coefficient is rapidly decreased as the dimensionless throat velocity increases. This means that, increasing the throat velocity has the same effect of increasing the Reynolds number, where the turbulence intensity increases with increasing Reynolds number. It is also noticed from this figure that, the total loss coefficient is decreased and then the diffuser performance is 
improved in the presence of aurtoll strut. Ihis is because the wasting area due to airfoil thickness accelerates the flow and this leads to a decrease in the loss coefficient, in addition to that the turbulence is intensified by the curvature of streamlines in the wake region. Also the figure indicates that the total loss coefficient decrease as the airfoil strut is located near to the throat, models 1 and 3. The total loss coefficient also decreases as the number of these struts is increased, models 1 and 2 . On the other hand, the effect of throat velocity on the total loss coefficient in the presence of the struts is relatively small regardless the thickness of struts and its position.

\section{4-3 Effect of strut on uniformity of flow}

The effect of strut location on the circumferential dimensionless velocity $(\lambda)$ distribution at the throat based on the measurements of the local circumferential static pressure are shown in Figs. (8) and (9) for the tested strut geometries while, Fig. (10) shows the variation of total loss coefficient. Circumferential variation of static pressure and dimensionless velocity $(\lambda)$ at the throat indicate high momentum deficiencies and may be caused due to hydraulic friction of the diffuser surface. The velocity defect is larger in case of airfoil struts because the flow may be separated from the strut surfaces. The cylindrical struts cause a reversible effect which will be spreaded in the opposite direction of flow till distort variation of velocity occurs at the throat. Also, it is seen that the variation of the dimensionless velocity $(\lambda)$ at the throat is more flatten when the strut is located near the exit section. Also, Fig. (10) shows that the total loss coefficient was found to be significantly greater on the casing than that on the hub of the diffuser, on account of the nonuniformity of flow at the diffuser entrance.

Figures (11) and (12) show the local separation which is seen by the accumulation of paints (black oil) on the surface of diffuser for both types of struts when they are located near the exit section. In these cases, total loss coefficient in the presence of cylindrical struts $\left(\zeta_{0}=0.3\right)$ is slightly smaller than that calculated in the case of airfoil strut $\left(\zeta_{0}=0.32\right)$ at the same dimensionless throat velocity.

\section{CONCLUSIONS}

Based on the results presented in this paper, the following conclusions are drawn regarding turbulent flow through annular diffusers:

1- The total loss coefficient of the tested diffuser decreased with the increasing of both the cylindrical strut diameter and the inlet throat dimensionless velocity $(\lambda)$.

2- The total loss coefficient of the tested diffuser increased when the strut was located near the throat of both types of struts.

3- The uniformity of the dimensionless velocity $(\lambda)$ at the throat perimeter is dependent upon the strut cross-section and its location.

4- Blockage, due to struts was found to be substantially increased the tendency of separation and, in turn, the diffuser performance is lowered.

5- Better performance was achieved with the cylindrical struts by increasing the turbulent mixing in the wake region, which, in turn, may reduce the inlet boundary layer blockage. 
6- The total loss coefficient due to non-uniformity of flow at the diffuser entrance was found to be significantly greater on the casing than that on the hub.

\section{REFERENCES:}

[1] Ainley, D.G., "Investigation of air flow through some annular diffusers", Power Jet Rept. 1151, Oct. 1945.

[2] Johnston, I.H., "The effect of inlet conditions on the flow in annular diffusers", A.R.C., Paper No. 178, 1954.

[3] Sovran, G. and Klomp, E.D., "Experimentally determined optimal geometries for rectilinear diffusers with rectangular, conical or annular cross section", Fluid Mechanics of Internal Flow, Ed. Sovran, G., Elsevier Publishing Co., pp. 270 - 319, 1967.

[4] Tyler, R.A. and Williamson, "Diffuser performance with distorted inflow", Symposium on subsonic fluid flow losses in complex passages and ducts, Paper No. 11, Inst. of Mech. Engineering, London, 1967.

[5] Stevens, S.J. and Fry, P., "Measurements of the boundary layer growth in annular diffusers", J. Aircraft, Vol. 10, pp. 73-80, 1973.

[6] Adenubi, S.O., "Performance and flow regime of annular diffusers with axial turbomachine discharge inlet conditions", Trans. ASME, J. Fluids Engineering, Vol. 98, No. 2, pp. 236-243, 1976.

[7] Stevens, S. J. and Williams, G.J., "The influence of inlet conditions on the performance of annular diffusers", Trans. ASME, J. Fluids Engineering, Vol. 102, pp. 357-363, 1980.

[8] Senoo, Y., Kawaguchi, N., Kojima, T. and Nishi, M., "Optimum strutconfiguration for downstream annular diffusers with variable swirling inlet flow", Trans. ASME, J. Fluids Engineering, Vol. 103, pp. 294-298,1981.

[9] Hoadley, D., "Three-Dimensional turbulent boundary layers in an annular diffuser", Ph.D. Thesis, Mechanical Engineering Dept., University of Cambridge, Cambridge, England, 1970.

[10] Klein, A., "Characteristics of combustor diffusers", Proc. Aerospace Sci, Vol. 31, pp. 171-271, 1995.

[11] Ubertini S. and Desideri U., "Flow development and turbulence length scales within an annular gas turbine exhaust diffuser", Experimental Thermal and Fluid Science, Vol. 22, pp. 55-70, 2000.

[12] Ubertini S. and Desideri U, "Experimental performance analysis of an annular diffuser with and without struts", Experimental Thermal and Fluid Science, Vol. 22, pp. 183-195, 2000.

[13] Kline, S.J. and McClintock, F. A. "Describing uncertainties in singlesample experiments", ASME, Mech. Engg. Journal, pp. 3-8 Jun.,

[14] Shapiro, H., "The dynamics and thermodynamics of compressible fluid flow", Volume 1, The Ronald Press Company, New York, 1953. 


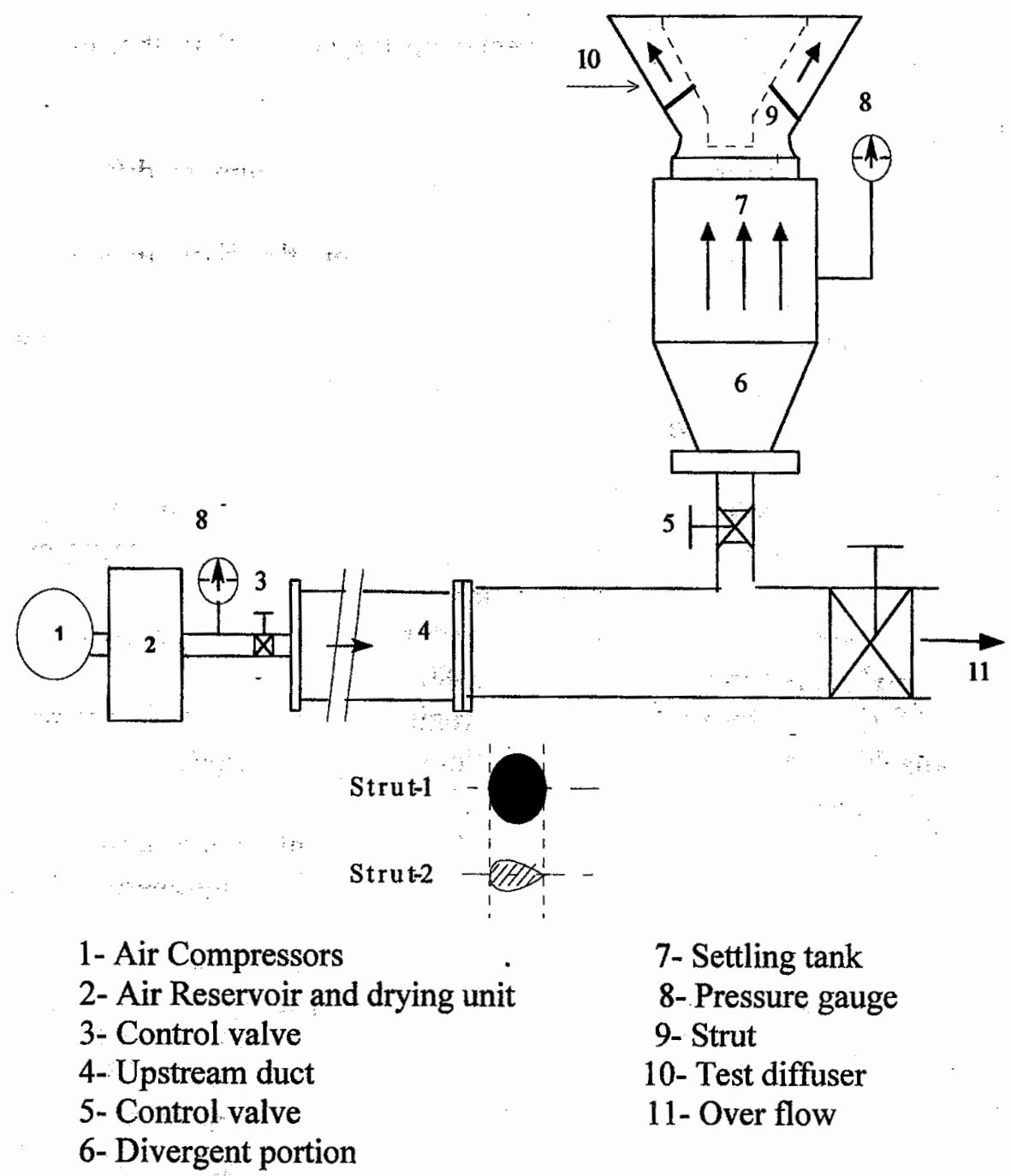

Fig. (1) General arrangement of experimental facility.

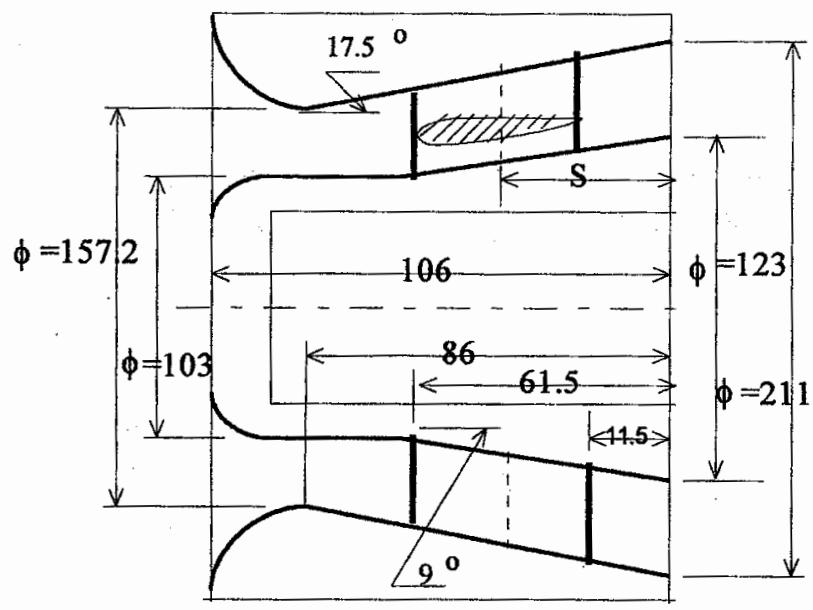

Dimensions in $\mathrm{mm}$

Fig. (2) Geometry of tested diffuser. 


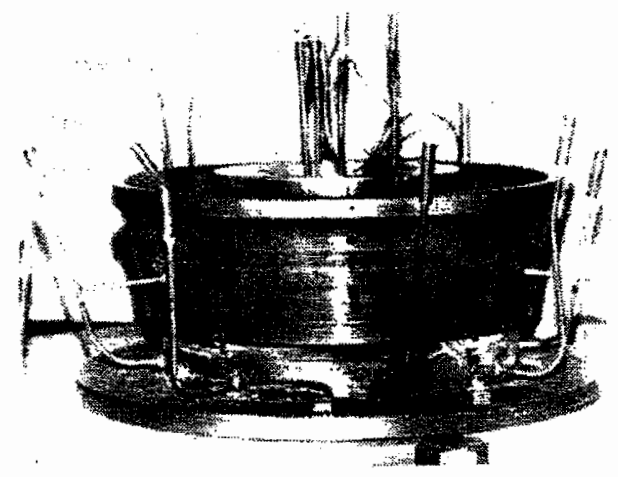

Fig. (3) Photograph of tested diffuser.

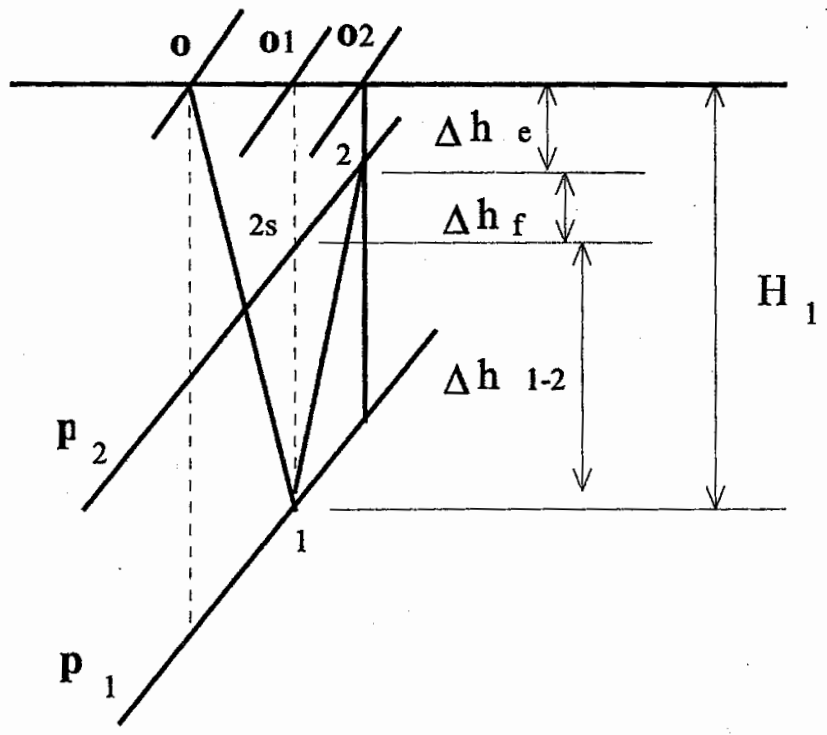

Fig. (4) h-S diagram of flow through diffuser.

Table (1) Characteristics of tested diffusers, (+ case study).

\begin{tabular}{|c|c|c|c|c|c|c|}
\hline \multirow[b]{2}{*}{ Model No. } & Type of strut & \multicolumn{4}{|c|}{ Diameter of strut in $\mathrm{mm}$} & \multirow[b]{2}{*}{ Airfoi } \\
\hline & $\begin{array}{c}\text { Number and location } \\
\text { of strut }\end{array}$ & 3 & 5.6 & 8 & 13.5 & \\
\hline 1 & $\mathrm{~N}=6, \mathrm{~S}=36 \mathrm{~mm}$ & - & - & - & - & + \\
\hline 2 & $\begin{array}{l}\mathrm{N}=3, \mathrm{~S}=36 \mathrm{~mm} \\
\mathrm{~N}=3, \mathrm{~S}=49 \mathrm{~mm}\end{array}$ & - & 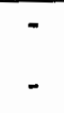 & - & - & + \\
\hline 3 & $\mathrm{~N}=6, \mathrm{~S}=17 \mathrm{~mm}$ & - & - & - & - & + \\
\hline 4 & $\mathrm{~N}=6, \mathrm{~S}=10 \mathrm{~mm}$ & + & + & + & + & - \\
\hline 5 & $\mathrm{~N}=6, \mathrm{~S}=36 \mathrm{~mm}$ & + & + & + & - & - \\
\hline 6 & $\begin{array}{l}\mathrm{N}=3, \mathrm{~S}=10 \mathrm{~mm} \\
\mathrm{~N}=6, \mathrm{~S}=36 \mathrm{~mm}\end{array}$ & $\begin{array}{l}+ \\
+\end{array}$ & - & - & - & - \\
\hline
\end{tabular}




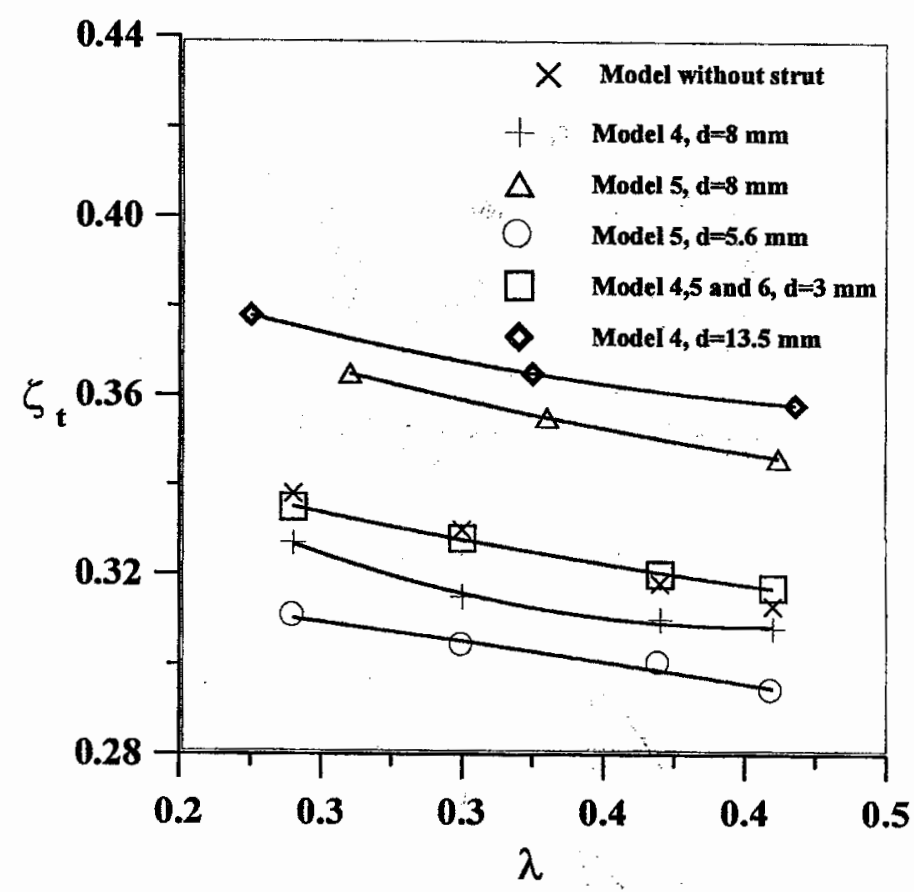

Fig. (5) Effect of throat dimensionless velocity $(\lambda)$ on the total loss coefficient for different diameters of cylindrical strut

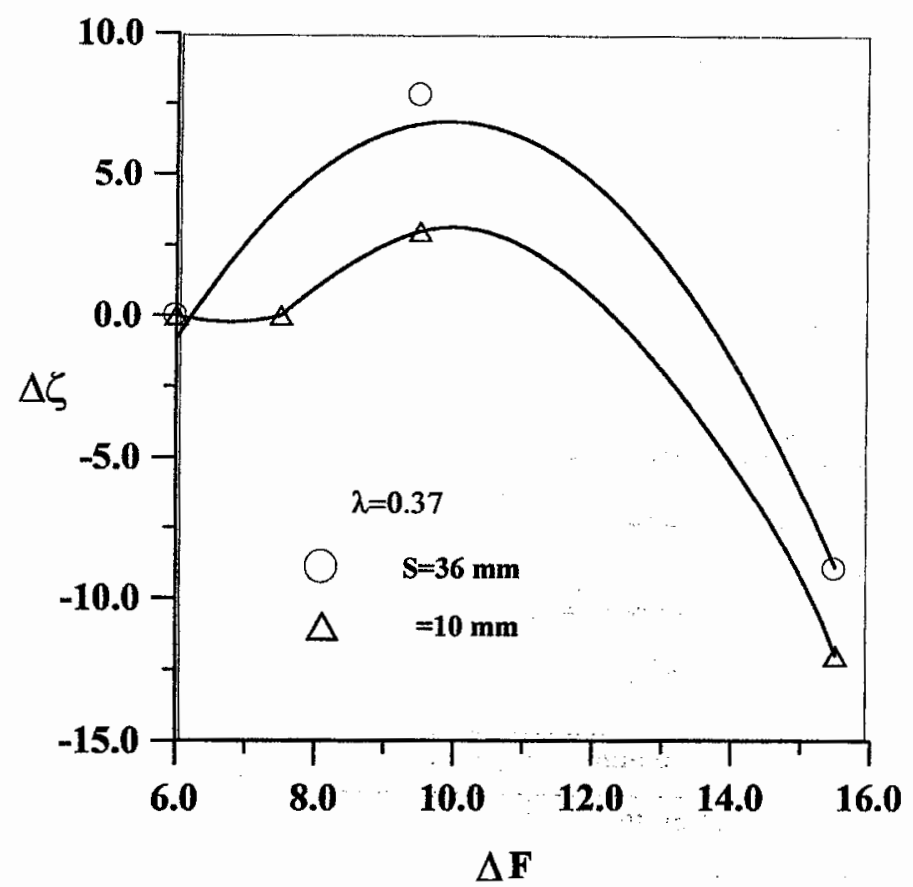

Fig. (6) Effect of strut blockage on the total loss coefficient for different locations of cylindrical strut 


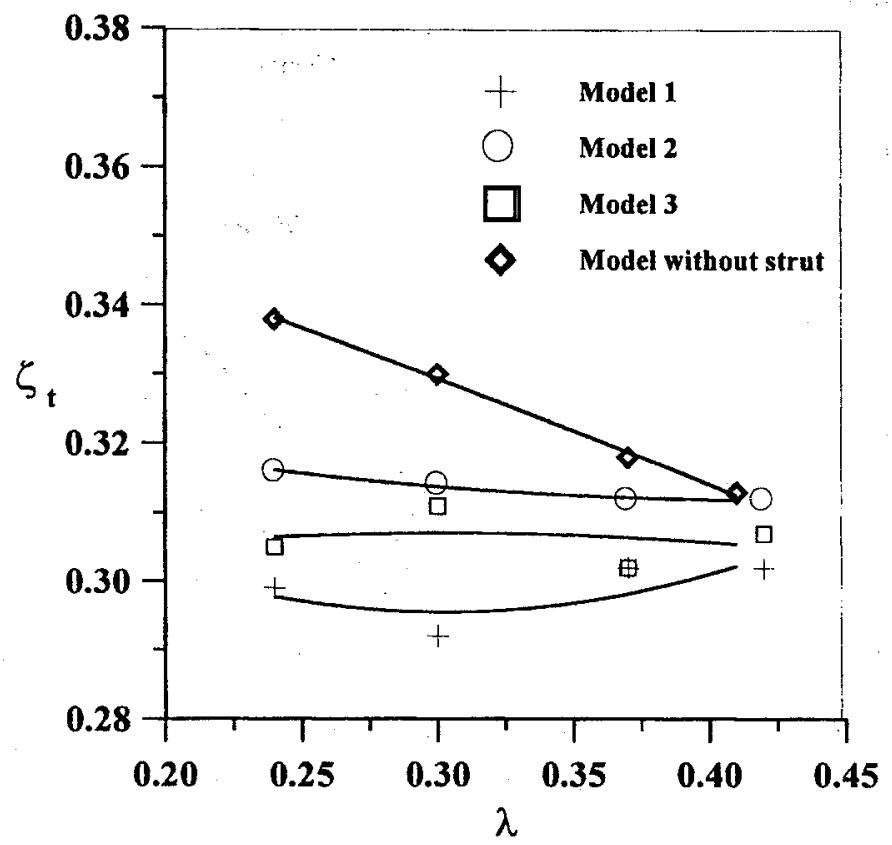

Fig. (7) Effect of throat dimensionless velocity $(\lambda)$ on the total loss coefficient for different models of airfoil strut

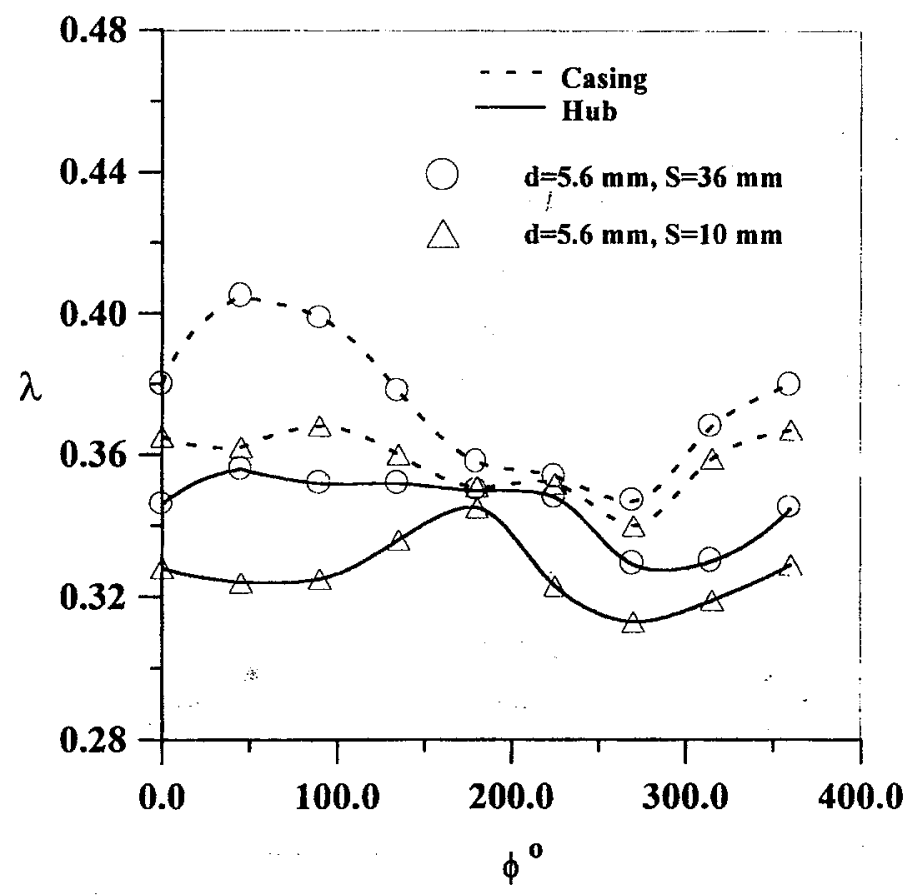

Fig. (8) Variation of circumferential throat dimensionless velocity $(\lambda)$ at different locations of cylindrical strut. 


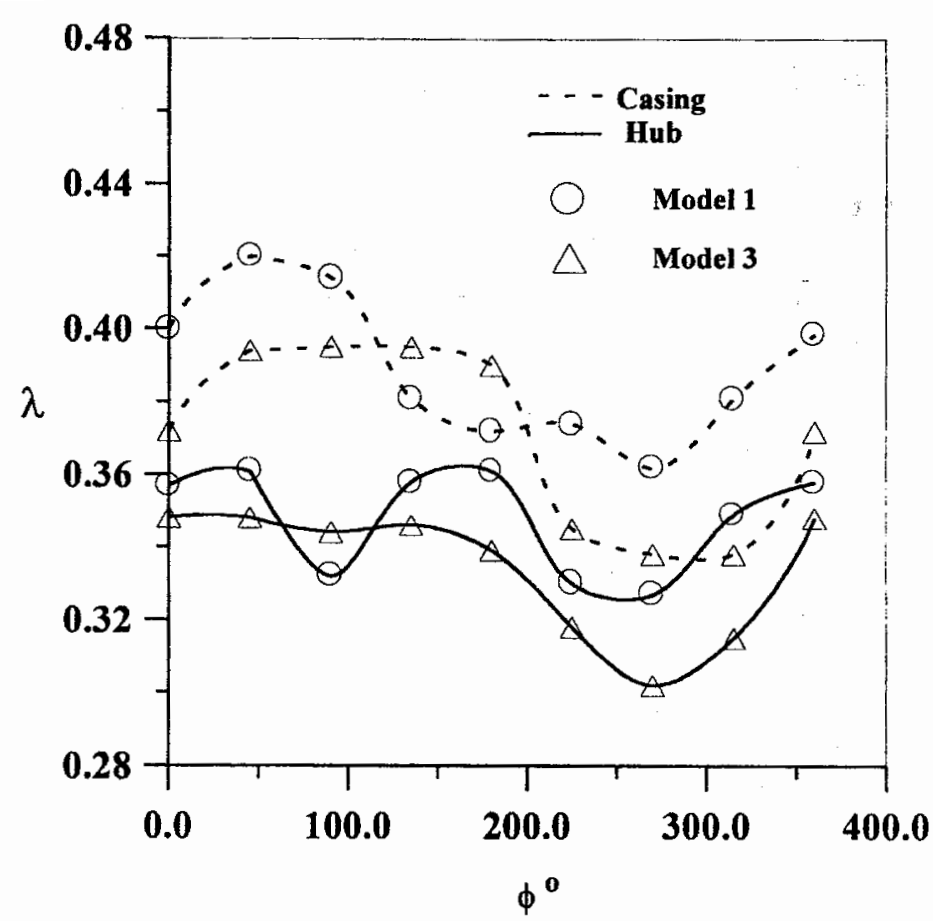

Fig. (9) Variation of circumferential throat dimensionless velocity $(\lambda)$ for different models of airfoil strut.

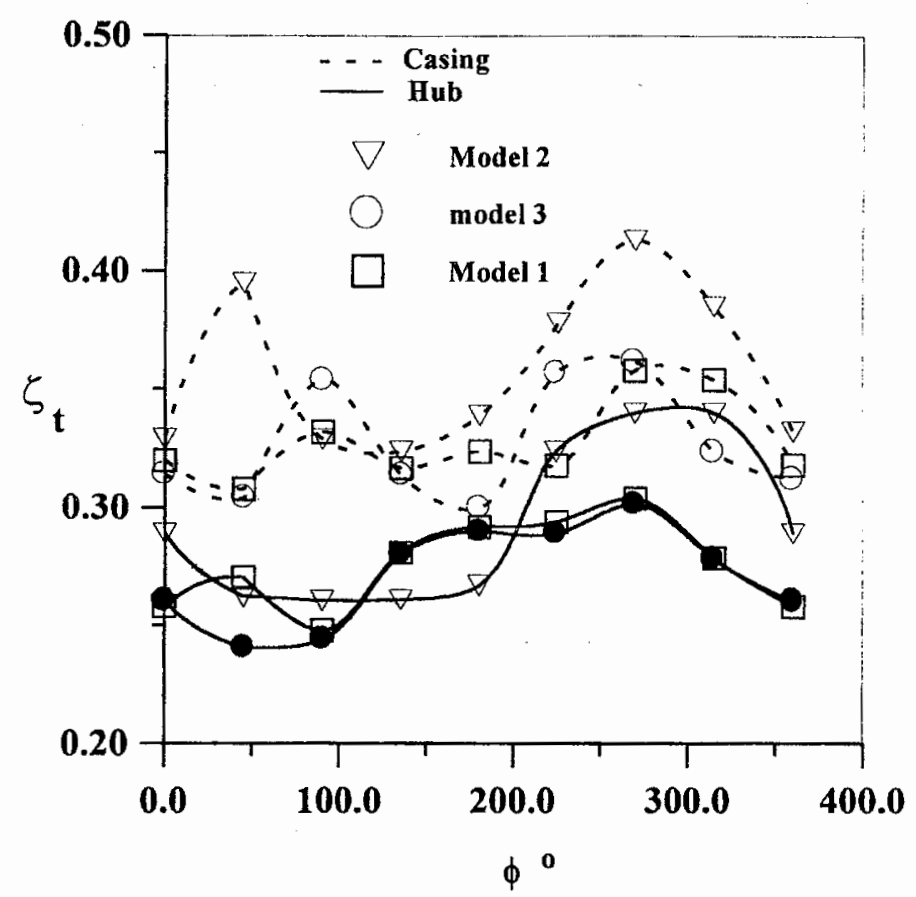

Fig. (10) Effect of non-uniformity of flow on the variation of total loss coefficient for different models of airfoil strut. 


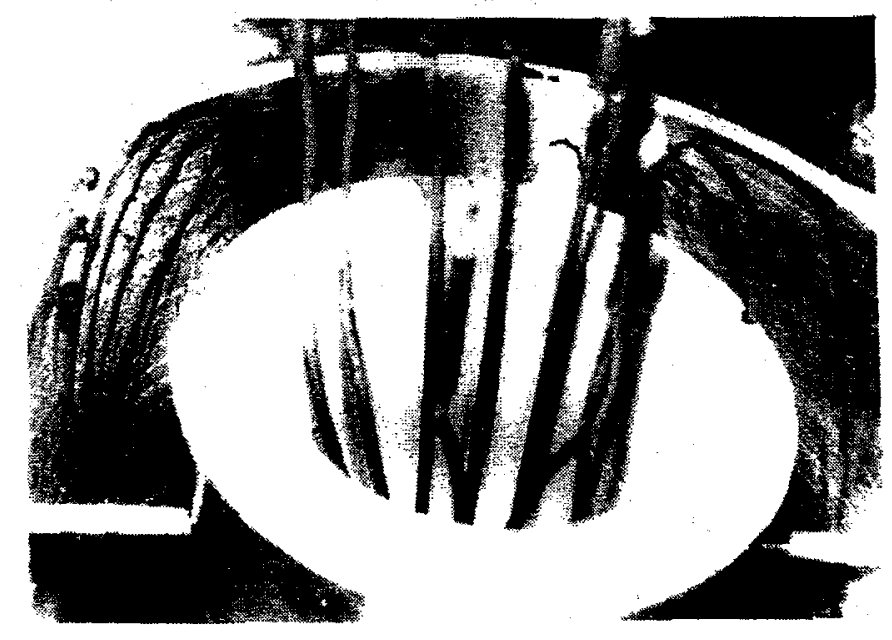

Fig. (11) Flow pattern in the case of cylindrical strut

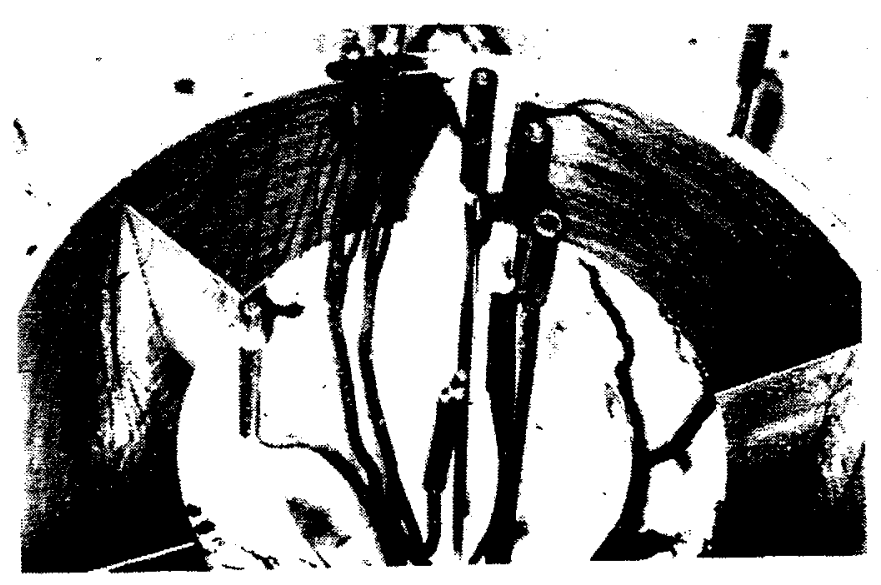

Fig. (12) Flow pattern in the case of airfoil strut 


\section{" در اسه معمليه لادام ناشتر حلمى"}

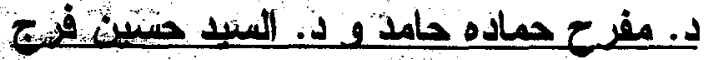

ملخص البحث :

8

هذا البحث بتتاول دراسة معملية للسريان الاضطر ابى خلال ناشر حلى لــه

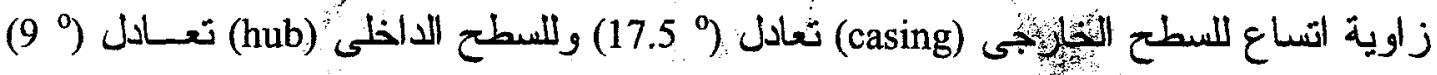

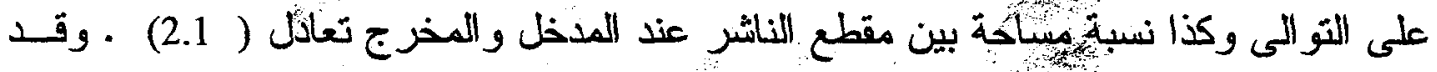
أجريت التجارب لفحص السريان الاضطر ابى خلال الناشر الحلقى عند قيم مختلفة للســرعة

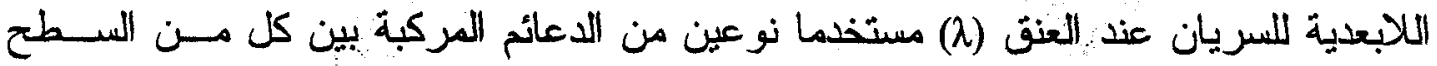
الخارجى و الداخلى. وكان النوع الأول من هذه الدعائم ذات مقطع أسطو اني بقطر ينز اوح بين (45 mm) بينما كان النوع الثاني ذات مفطع متغير (ايروفيل) ذو ونز يعسادل (3-13.5mm) وكان أقصى سمك لها يعادل (2.7 mm). وكان الهذف من الدر اسة هو دراسة نأثير وجود منل هذه الدعائم داخل الناشر الحلقى على أداء هذا الناشر كما ثم الأخذ فى الاعتبار موضع هـذه الدعائم و عددها. وقد أجريث هذه التجارب وتم أخذ النتائج عند رقم رينولدز (Re) بيتر اوح بين (2x10 - 5x10 $)$

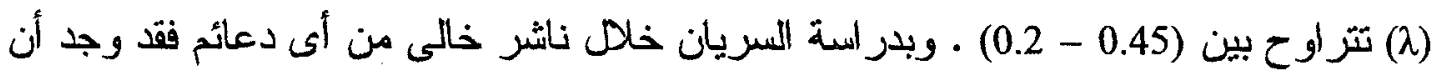
المفاقيد الكلية خله الناشر تقل بمعدل كبير بزيادة السرعة اللابعدية عند العنق (ג) وذلك لأن

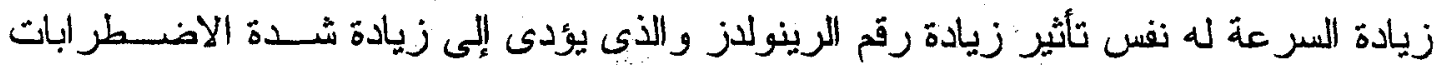
(turbulence intensity) محيط مقطع الناثر عند إلعنق تعتمد على شكل الدعائم المركبة و كذا موضعها وعددها. كما أظهرت النتائج أن أداء الناشر يتأثز بعدد الدعائم المركبة داخل الناشر وكذا أبعادها. وقد تبين من النتائج ظهور هبوط في أدله الناشر بزيادة قطر الدعامة الاسطو انية المســـخدمة (النــوع الأول). كما وجد فى حالة وجود الاعائم أنه يمكن التحكم فى ظاهرة أففسال السريان بســبب الانسداد الناتج عند المدخل و الناتج عن وجود هذه الاعائم. علاوة على ذلـلك تبــين أن الألاء الكلى للنواشر المختبرة و التى يظهر بها انفصال للسريان لا يتأثر كثيـرا بوجهـود الـدعائم الأسطو انية ذات القطر الصغير وعلى الجانب الأخر كانت الفائدة من وجودها هو التحكم فـى انفصل السريان. وكانت إحدى نتائج هذا البحث هى أنه يمكن تحديد الترثيب المثالى (القطــر و الموضـ) و الأى يعطى أقل مفاقبد كلية وبالتّالى أفضل أداء. كما وجد من النتائج أيضـــا أن المفاقيد الكلية و الناتجة عن عدم النتظام السريان على المحيط عند العنق على السطح العلــوى أكبر منها على السطح السفلى فى الحالات المستخدمة. 